DOI https://doi.org/10.30525/978-9934-26-109-1-4

\title{
ІНФОРМАЦІЙНА МОДЕЛЬ УПРАВЛІННЯ ВАРТІСТЮ, ТРИВАЛІСТЮ ТА ЯКІСТЮ ПРОЕКТІВ З ЕКСПЛУАТАЦІЙНОГО УТРИМАННЯ ДОРІГ
}

\author{
Харченко А. М. \\ кандидат технічних наук, дочент, \\ доцент кафедри транспортного будівництва та управління майном \\ Національний транспортний університет \\ м. Київ, Украӥна \\ Заворотний С. М. \\ інженер-землевпорядник \\ Приватне підприємство «ЕЛІТЗЕМ» \\ м. Чернігів, Украӥна

\section{Цибульський В. М.} \\ старший викладач кафедри опору матеріалів та машинознавства \\ Національний транспортний університет

$$
\text { м. Київ, Украӥна }
$$

Успішна реалізація проекту залежить від правильно визначеного переліку факторів, які можуть впливати на процес його реалізації. Проекти з експлуатаційного утримання автомобільних доріг не $\epsilon$ виключенням, адже їх реалізація залежить від таких трьох основних складових, як час, вартість та якість [1]. Зважаючи на складність визначення взаємозв'язку відношення між цими складовими, які утворюють загальновідомий в практиці управління проектами «срібний трикутник», виникає необхідність в обгрунтуванні факторів та побудові інформаційної моделі управління вартістю, тривалістю та якістю проектів з експлуатаційного утримання доріг.

Засновником «срібного трикутника» був Мартін Барнс [2], який визначив, що якість, вартість та час взаємопов'язані, а фокусування або вирішення однієї мети трикутника впливає на інші два фокуси. Окрім цього, фактори трикутника балансуються за цілями та викликами задачі управління. Найчастіше у розв'язку задач управління один 3 факторів $\epsilon$ фіксованим, а два інших $є$ змінними у зворотній пропорції між собою. 
Таким чином, успішна реалізація проектів 3 експлуатаційного утримання автомобільних доріг залежить від моделі управління часом, вартістю та якістю контрактів $[1 ; 3]$.

Побудова якісної інформаційної моделі взаємозв'язку параметрів «срібного трикутника» $\epsilon$ дуже складним та багатопараметричним процесом. Це пов'язано, по-перше, з необхідністю враховувати велику кількість факторів, що впливають один на одного та безпосередньо на одну або декілька складових трикутника, по-друге, з постійною змінністю переліку цих факторів, кількість яких залежить від особливостей проекту експлуатаційного утримання автомобільних доріг.

Розглянемо кожну складову інформаційної моделі окремо. Наприклад, час реалізації проекту, може описуватися функцією, основними змінними якої з точки зору експлуатаційного утримання доріг будуть $[4 ; 5 ; 6]$ :

- тривалість виконання основних (запланованих) робіт;

- тривалість виконання незапланованих та допоміжних робіт;

- особливість кліматичних та грунтово-геологічні умови, який залежить від географічне місце знаходження об'єкту;

- швидкість роботи робочого персоналу, який залежить від кваліфікованість та досвід роботи організації виконавця;

- тривалість затримок, які виникли підчас реалізації проекту.

До факторів, які впливають на функцію вартості реалізації проекту слід віднести:

- вартість матеріалів, технічного забезпечення, виробів та напівфабрикатів, яка залежить від їх якості;

- обсяг робіт;

- вартість виконання робіт, яка залежить від рівня кваліфікації та досвідченості робочого персоналу;

- рівень складності виконання робіт, яка залежить від специфіки об'єкту та його категорії;

- штрафи та стимулюючі виплати;

- інфляція;

- якість фінансування контракту на різних етапах його виконання, яка залежить від умов контракту та економічного стану замовника.

Характеристики, які суттєво впливають на якість у проектах експлуатаційного утримання доріг включають:

- державні вимоги до якості виконання робіт, які залежать від рівня якості, що вказані, наприклад, в ДБН, ВБН, ДСТУ, ТУ тощо, і не 
можуть бути порушені тобто бути меншими ніж зазначено в технічній документації;

- споживчі вимоги та потреби, які залежать від потреб місцевого населення та необхідного рівня якості конкретного регіону чи району, вони можуть бути більшими ніж нормативні;

- міжнародні вимоги та норми, які залежать від норм та правил, що прийняті та затверджені на міжнародному рівні.

Зазначені фактори не $\epsilon$ сталими, вони будуть змінюватись відповідно до особливостей проекту на експлуатаційне утримання доріг, проте, врахування мінімального переліку в інформаційній моделі управління проектами дасть змогу підвищити ефективність прийнятих управлінських рішень.

\section{Література:}

1. Заворотний С.М., Харченко А.М. Фактори, які впливають на час, вартість та якість реалізації довгострокових контрактів заснованих на кінцевих показниках. Управління проектами, системний аналіз $i$ логістика. Київ, 2017. Вип. 20. С. 41-49.

2. Barnes, M. Some origins of modern project management-A personal history. 2006. URL: http://www.pmforum.org/viewpoints/2006/08_4.htm.

3. Carl Chatfield and Timothy Johnson. A short course in project management. URL: http://office.microsoft.com/en-us/project/ HA102354821033.aspx.

4. Chidambaram Ramanathan, SP Narayanan, Arazi B Idrus. Construction Delays Causing Riskson Time and Cost - a Critical Review. Australasian Journal of Construction Economics and Building. Universiti Teknologi Petronas, Malaysia. URL: https://doi.org/10.5130/ AJCEB.v12i1.2330.

5. Bordat C., McCullouch B.G., Labi S., Sinha K.C. An Analysis of Cost Overruns and Time Delays of INDOT Projects. Publication FHWA/IN/JTRP2004/07. Joint Transportation Research Program, Indiana Department of Transportation and Purdue University, West Lafayette, Indiana, 2004. doi: 10.5703/1288284313134. URL: https://docs.lib.purdue.edu/cgi/ viewcontent.cgi?referer=https://www.google.com.ua/ $\&$ httpsredir $=1 \&$ article $=$ $1482 \&$ context $=$ jtrp.

6. Understanding and Monitoring the Cost-Determining Factors of Infrastructure Projects. A User's Guide. European Commission. Directorate Generalfor Regional Policyand Cohesion, 1998. URL: https://www. google.com.ua/?gws_rd=ssl\#q=4.\%09Understanding+and+Monitoring+the+ Cost-Determining+Factors+of+Infrastructure+Projects.+A+User\%27s+Guide. 